\title{
Sufficiency ranges for lemon balm and nutrient removals in aboveground phytomass
}

\section{M. Ângelo Rodrigues, Isabel Q. Ferreira, Sandra Afonso \& Margarida Arrobas}

To cite this article: M. Ângelo Rodrigues, Isabel Q. Ferreira, Sandra Afonso \& Margarida Arrobas (2018) Sufficiency ranges for lemon balm and nutrient removals in aboveground phytomass, Journal of Plant Nutrition, 41:8, 996-1008, DOI: 10.1080/01904167.2018.1431671

To link to this article: https://doi.org/10.1080/01904167.2018.1431671

册 Published online: 23 Feb 2018.

Submit your article to this journal $\pi$

山 Article views: 37

View Crossmark data ¿ 


\title{
Sufficiency ranges for lemon balm and nutrient removals in aboveground phytomass
}

\author{
M. Ângelo Rodrigues, Isabel Q. Ferreira, Sandra Afonso, and Margarida Arrobas \\ Mountain Research Centre - Polytechnic Institute of Bragança, Campus de Santa Apolónia, Bragança, Portugal
}

\begin{abstract}
A set of fertilizer experiments were conducted during three growing seasons with the aim of establishing sufficiency ranges and crop nutrient removals for Melissa officinalis L. Critical nutrient concentrations were determined by the Cate-Nelson method or by removing $10 \%$ of extreme high and low values, respectively if a positive response to a given nutrient was recorded or not. Sufficiency ranges for macro, micronutrients, and SPAD-readings were set as: $27.0-40.0 \mathrm{~g} \mathrm{~N} \mathrm{~kg}^{-1} ; 0.8-$ $2.7 \mathrm{~g} \mathrm{P} \mathrm{kg}^{-1}$ (May-August); $1.5-3.8 \mathrm{~g} \mathrm{P} \mathrm{kg}^{-1}$ (September-November); 10.0-25.0 g $\mathrm{K} \mathrm{kg}^{-1}$ (May-August); 18.0-32.0 $\mathrm{g} \mathrm{K} \mathrm{kg}^{-1}$ (September-November); $5.0-25.0 \mathrm{~g} \mathrm{Ca}$ $\mathrm{kg}^{-1} ; 3.5-8.5 \mathrm{~g} \mathrm{Mg} \mathrm{kg}^{-1} ; 18-125 \mathrm{mg} \mathrm{B} \mathrm{kg}^{-1} ; 5-25 \mathrm{mg} \mathrm{Cu} \mathrm{kg}^{-1} ; 75-500 \mathrm{mg} \mathrm{Fe}$ $\mathrm{kg}^{-1} ; 20-300 \mathrm{mg} \mathrm{Zn} \mathrm{kg}^{-1} ; 30-250 \mathrm{~g} \mathrm{Mn} \mathrm{kg}^{-1} ; 30-45$ SPAD-units. These results will allow laboratories to use plant analysis as an important tool in improving the fertilizer recommendations for this species.
\end{abstract}

\section{ARTICLE HISTORY}

Received 15 November 2016 Accepted 28 September 2017

\section{KEYWORDS}

critical concentrations; Melissa officinalis; plant analysis; SPAD readings; threshold values

\section{Introduction}

Lemon balm is a perennial herbaceous plant of the Lamiaceae family native to Central and Southern Europe, North Africa, and Central Asia (Babulka 2005). The leaves of lemon balm have a mild lemon scent which makes the plant useful as a flavoring in dishes, ice cream, and herbal teas. The essential oil is also very popular in aromatherapy (Babulka 2005; Sodré et al. 2012). Lemon balm has been prescribed for several medicinal uses such as the treatment of disorders of the gastrointestinal tract, as an anxiolytic agent, and against viral infections (Grünwald and Jänicke 2009; Cunha, Nogueira, and Roque 2012). Its use as an insect repellent has also been reported (Ashori, Hamzeh, and Amani 2011).

The use of lemon balm in folk medicine and its multiple perceived health benefits have led to intense research activity in the fields of phytotherapy and pharmacognosy. Several studies have been conducted to evaluate the chemical composition of lemon balm (Pereira et al. 2014), its anxiolytic activity (Vafaei et al. 2005; Taiwo et al. 2012), and nutraceutical and antioxidant properties (Dias et al. 2012; Luño et al. 2015) as well as its potential as an antimicrobial (Stanojevic et al. 2010; Rabbani et al. 2016), a neuroprotective (López et al. 2009; Kamdem et al. 2013), or a carcinopreventive (Sousa et al. 2004; Weidner et al. 2015) agent.

The relevant literature on this species in the biochemical and pharmaceutical fields contrasts with the limited available data on the agronomy of the crop. Some papers can be found on several aspects of cropping technique, but they are usually studies of short duration and the majority are published in national journals, rarely in English, containing limited data and not easily accessible to the international scientific community. There can be found agronomic studies on lemon balm focused on cover cropping strategies (Biasi et al. 2009), harvesting regimes (Blank et al. 2005; León-Fernández et al. 2008; May et al. 2008), and water requirements (Ghamarnia, Mousabeygi,

CONTACT M. Ângelo Rodrigues angelor@ipb.pt Mountain Research Centre - Polytechnic Institute of Bragança, Campus de Santa Apolónia, 5300-253 Bragança, Portugal.

(C) 2018 Taylor \& Francis Group, LLC 
and Arji 2015). However, crop fertilization has probably been the agronomic aspect that has received the greatest attention. Studies can be found on lime application (Blank et al. 2006), organic amendment (Santos et al. 2009; Sodré et al. 2013), and mineral fertilization by combining diverse rates of the major nutrients (Blank et al. 2006; May et al. 2008; Sodré et al. 2013; Sharafzadeh, Khosh-Khui, and Javidnia 2011; Németh-Zámboriné et al. 2015). These studies usually seek to assess the effect of manures and fertilizers on biomass yield and/or essential oil production, but there are other important aspects such as nutrient concentration in plant tissues. Unlike for most other crops, critical sufficiency ranges or threshold values, which are essential for establishing a proper fertilization program, are not available for this species. It should be noted that Bryson et al. (2014) compiled sufficiency ranges for more than 2,000 cultivated species, from herbaceous crops, fruit growing, forestry and ornamentals, but they did not include lemon balm. As far as we know, such data is currently not available for a crop with such economic potential and broad distribution as the lemon balm. In practice, if a farmer wanted to monitor the nutritional status of this crop, or to establish a fertilization program based on plant analysis, it would not be possible due to the lack of leaf nutrient concentration standards for the interpretation of results.

This work was carried out with the aim of fulfilling four main objectives: i) to assess the effect of four individual important nutrients [nitrogen $(\mathrm{N})$, phosphorus $(\mathrm{P})$, potassium $(\mathrm{K})$, or boron $(\mathrm{B})$ ] on crop dry matter yield in a varied range of conditions; ii) to establish threshold leaf nutrient concentrations and sufficiency ranges for $\mathrm{N}, \mathrm{P}, \mathrm{K}$, calcium $(\mathrm{Ca})$, magnesium $(\mathrm{Mg}), \mathrm{B}$, copper $(\mathrm{Cu})$, iron $(\mathrm{Fe})$, zinc $(\mathrm{Zn})$, and manganese $(\mathrm{Mn})$; iii) to set a sufficiency range for SPAD-readings, a $\mathrm{N}$ nutritional index that can be obtained with a portable device without the need for sending plant samples to the lab; and iv) to estimate crop nutrient removals in the harvested biomass, an important parameter in fertilizer recommendations since it may indicate the needs of the crop.

\section{Materials and methods}

\section{Study site}

The experiments were carried out in Bragança $\left(41^{\circ} 48^{\prime} \mathrm{N}, 6^{\circ} 44^{\prime} \mathrm{W}\right)$, NE Portugal. The region of Bragança benefits from a Mediterranean type climate, somewhat influenced by the Atlantic regime. The mean annual air temperature and annual precipitation in the period 1971-2000 were, respectively, $12.3^{\circ} \mathrm{C}$ and $758 \mathrm{~mm}$. Mean monthly temperatures and precipitation recorded during the experimental period are presented in Figure 1.

The experimental apparatus included four field trials that took place in 2013 and 2014 and eight pot experiments carried out in 2013 (1), 2014 (3), and 2015 (4). The field trials were carried out in a Leptosol (WRBSR 2014) originating from a bed-rock of schist. The cultivated plot was prepared in terraces to reduce the slope and to facilitate cultivation. The properties of a soil sample from this field and also from the soils used in the pot experiments are presented in Table 1.

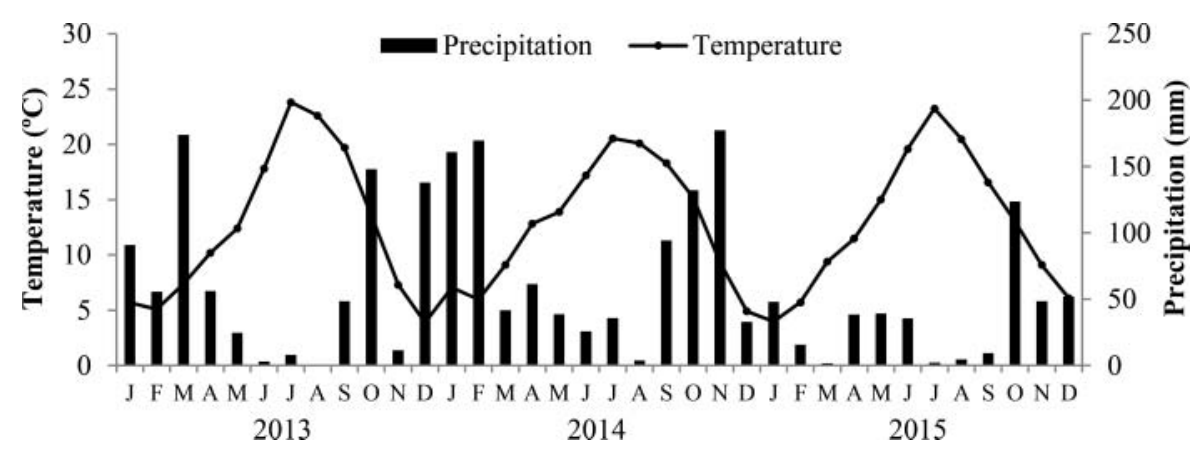

Figure 1. Average monthly temperature (line) and accumulated precipitation (bars) during the experimental period recorded in the weather station of Qta de Sta Apolónia, Bragança. 
Table 1. Selected properties of the soils $(0-20 \mathrm{~cm})$ of the field trials (FieldT) and those used in the pot experiments of 2013 (Pot2013), 2014 (Pot2014), and 2015 (Pot2015).

\begin{tabular}{|c|c|c|c|c|}
\hline Soil properties & FieldT & Pot2013 & Pot2014 & Pot2015 \\
\hline Clay (\%) & 9.5 & 10.4 & 16.9 & 22.5 \\
\hline Silt (\%) & 14.8 & 18.9 & 18.2 & 20.1 \\
\hline Sand (\%) & 75.7 & 70.7 & 64.9 & 57.4 \\
\hline Texture (USDA) & Sandy loam & Sandy loam & Sandy loam & Sandy loam \\
\hline $\mathrm{pH}_{\mathrm{H} 2 \mathrm{O}}$ & 6.3 & 6.5 & 6.0 & 6.3 \\
\hline $\mathrm{pH}_{\mathrm{KCl}}$ & 4.8 & 5.9 & 5.3 & 5.3 \\
\hline Organic $C\left(\mathrm{~g} \mathrm{~kg}^{-1}\right)^{\mathrm{a}}$ & 9.0 & 14.5 & 8.4 & 6.8 \\
\hline Extractable $\mathrm{P}\left(\mathrm{mg} \mathrm{kg}^{-1}\right)^{\mathrm{b}}$ & 23.9 & 281.5 & 58.0 & 41.0 \\
\hline Extractable $\mathrm{K}\left(\mathrm{mg} \mathrm{kg}^{-1}\right)^{\mathrm{b}}$ & 57.0 & 132.5 & 51.9 & 104.0 \\
\hline \multicolumn{5}{|l|}{ Exchangeable bases $^{c}$} \\
\hline $\mathrm{Ca}\left(\mathrm{cmol}_{\mathrm{c}} \mathrm{kg}^{-1}\right)$ & 6.2 & 7.6 & 13.1 & 12.1 \\
\hline $\mathrm{Mg}\left(\mathrm{cmol}_{\mathrm{c}} \mathrm{kg}^{-1}\right)$ & 3.2 & 2.2 & 3.7 & 4.2 \\
\hline $\mathrm{K}\left(\mathrm{cmol}_{\mathrm{c}} \mathrm{kg}^{-1}\right)$ & 0.3 & 0.3 & 0.2 & 0.4 \\
\hline $\mathrm{Na}\left(\mathrm{cmol}_{\mathrm{c}} \mathrm{kg}^{-1}\right)$ & 0.5 & 0.2 & 0.3 & 0.5 \\
\hline
\end{tabular}

${ }^{a}$ Walkley-Black (Motsara and Roy 2008); ${ }^{b}$ Egner-Riehm (Egnér, Riehm, and Domingo 1960); ${ }^{\mathrm{c} A m m o n i u m-a c e t a t e, ~ p H ~} 7$ (Motsara and Roy 2008).

\section{Experimental designs and crop management}

The field trials were carried out over two years, during the growing seasons of 2013 and 2014, in a commercial field organically managed. They consisted in N (FieldN), P (FieldP), K (FieldK), and B (FieldB) fertilizer trials. The experiments were arranged as completely randomized designs with four $\mathrm{N}(0,50$,

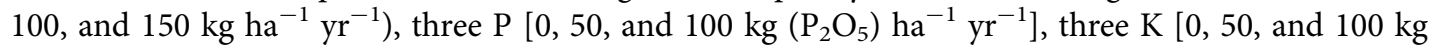
$\left.\left(\mathrm{K}_{2} \mathrm{O}\right) \mathrm{ha}^{-1} \mathrm{yr}^{-1}\right]$ and three $\mathrm{B}\left(0,1\right.$, and $\left.2 \mathrm{~kg} \mathrm{ha}^{-1} \mathrm{yr}^{-1}\right)$ rates and three replications. The plots of a given nutrient received also a basal fertilization plan with the nutrients not included in the experimental design. The basal fertilization plan consisted of the application of $100 \mathrm{~kg} \mathrm{~N}, \mathrm{P}\left(\mathrm{P}_{2} \mathrm{O}_{5}\right)$ and $\mathrm{K}\left(\mathrm{K}_{2} \mathrm{O}\right)$ $\mathrm{ha}^{-1} \mathrm{yr}^{-1}$, and $2 \mathrm{~kg} \mathrm{~B} \mathrm{ha}^{-1} \mathrm{yr}^{-1}$. Each individual plot consisted of six rows $2.8 \mathrm{~m}$ long. The ground was covered with a plastic anti-weed mat punched with holes spaced at $40 \times 40 \mathrm{~cm}$ which defines the planting density. The field was drip-irrigated from May to September. The nutrients were supplied as a nutrient solution prepared from fertilizers authorized for organic farming. To supply the nutrients required in the experimental design the commercial fertilizers fosfigen $(0: 30: 20)$, organihum $\mathrm{P}$ (8\% $\left.\mathrm{P}_{2} \mathrm{O}_{5}, 2 \% \mathrm{~N}\right)$, organihum $\mathrm{K}\left(30 \% \mathrm{~K}_{2} \mathrm{O}, 2 \% \mathrm{~N}\right)$, organihum nitro $(8 \%$ total $\mathrm{N})$, and neobor $(15 \% \mathrm{~B})$ were applied. The concentrations of the nutrient solutions were established by taking into account the plant spacing, the rate of nutrients to apply per hectare, and the volume of nutrient solution applied to each plant $(50 \mathrm{~mL})$. To reduce the salt effect and to increase nutrient use efficiency, the total amount of nutrients was split in four applications thereabout monthly spaced. After being prepared the nutrient solution was poured into the holes of the mat surrounding the plants.

In 2013 a pot experiment was carried out. It consisted of an $\mathrm{N}$ fertilization experiment (PotN2013) arranged as a completely randomized design with four $\mathrm{N}$ rates $\left(0,0.45,0.90,1.35 \mathrm{~kg} \mathrm{~N}_{\text {pot }}{ }^{-1}\right)$ and six replications (six pots). All the pots also received $0.90 \mathrm{~g}\left(\mathrm{P}_{2} \mathrm{O}_{5}\right)$ and $\left(\mathrm{K}_{2} \mathrm{O}\right)$ pot $^{-1}$ and a mixture of macro and micronutrients in a commercial formulation marketed as oligomag $\left(10 \% \mathrm{MgO}, 0.3 \% \mathrm{~B}, 18.5 \% \mathrm{SO}_{3}\right.$, $0.3 \% \mathrm{Cu}, 2 \% \mathrm{Fe}, 1 \% \mathrm{Mn}, 0.02 \% \mathrm{Mo}, 1.6 \% \mathrm{Zn}$ ) applied at a rate of $0.08 \mathrm{~g} \mathrm{plot}^{-1}$. The fertilizers used were the same as those in the field experiment. The pots were filled with $4 \mathrm{~kg}$ of dry and sieved (mesh of $2 \mathrm{~mm}$ ) soil mixed with $15 \mathrm{~g}$ perlite $\mathrm{kg}^{-1}$ dry soil. The fertilizers were added as a nutrient solution split into four applications during the growing season. The pots were placed in holes in the ground lined with PVC pipe to protect the walls of the pots from direct sunlight and to avoid overheating of the rhizosphere. Cuttings of 8-12 cm height were transplanted on 21 March. During the growing season the pots were watered as necessary to allow normal plant growth.

In 2014, three pot experiments were carried out one for each of the nutrients $\mathrm{N}$ (PotN2014), P (PotP2014), and K (PotK2014). They consisted of completely randomized designs with four $\mathrm{N}(0,0.8$, 1.6, and $\left.2.5 \mathrm{~g} \mathrm{pot}^{-1}\right)$, three $\mathrm{P}\left[0,0.8\right.$, and $\left.1.6 \mathrm{~kg}\left(\mathrm{P}_{2} \mathrm{O}_{5}\right) \mathrm{ha}^{-1}\right]$, and three $\mathrm{K}\left[0,0.8\right.$ and $1.6 \mathrm{~kg}\left(\mathrm{~K}_{2} \mathrm{O}\right)$ 
$\operatorname{pot}^{-1}$ ] rates, and ten replications. The experiment of a given nutrient $(\mathrm{N}, \mathrm{P}$, or $\mathrm{K})$ received the other two as a basal fertilization plan, consisting of $1.6 \mathrm{~g} \mathrm{pot}^{-1}$ of $\mathrm{N}, \mathrm{P}\left(\mathrm{P}_{2} \mathrm{O}_{5}\right)$, and $\mathrm{K}\left(\mathrm{K}_{2} \mathrm{O}\right)$. The $\mathrm{N}, \mathrm{P}$, and $\mathrm{K}$ pots also received $0.08 \mathrm{~g}$ of oligomag. The nutrients were supplied as a nutrient solution prepared with the fertilizers used in the field trials and PotN2013. The experiment was started on 8 May from cuttings of 8-12 cm height. All other aspects of the fertilization plan and crop management were similar to that reported for PotN2013.

In 2015, four pot experiments were carried out, one for each of the nutrients $\mathrm{N}$ (PotN2015), $\mathrm{P}$ (PotP2015), K (PotK2015), and B (PotB2015). They were arranged as completely randomized designs with four rates of $\mathrm{N}, \mathrm{P}\left(\mathrm{P}_{2} \mathrm{O}_{5}\right)$, and $\mathrm{K}\left(\mathrm{K}_{2} \mathrm{O}\right)\left(0,1.6,3.2\right.$, and $\left.6.4 \mathrm{~kg} \mathrm{pot}^{-1}\right)$, and also four $\mathrm{B}(0,32,64$, and $\left.128 \mathrm{~g} \mathrm{pot}^{-1}\right)$ rates and three replications. The basal fertilization plan was composed of $2.4 \mathrm{~g} \mathrm{pot}^{-1}$ of $\mathrm{N}, \mathrm{P}\left(\mathrm{P}_{2} \mathrm{O}_{5}\right)$, and $\mathrm{K}\left(\mathrm{K}_{2} \mathrm{O}\right)$ and $0.08 \mathrm{~g}$ of oligomag. The $\mathrm{B}$ experiment did not receive oligomag, since it also contains $\mathrm{B}$. The nutrients were supplied as fertilizers ammonium nitrate $(34.5 \% \mathrm{~N})$, superphosphate $\left(18 \%, \mathrm{P}_{2} \mathrm{O}_{5}\right)$, potassium chloride $\left(60 \%, \mathrm{~K}_{2} \mathrm{O}\right)$, neobor $(15 \% \mathrm{~B})$, and oligomag. The high rates of fertilizers used in this experiment [estimated as $400 \mathrm{~kg} \mathrm{~N}, \mathrm{P}\left(\mathrm{P}_{2} \mathrm{O}_{5}\right)$ and $\mathrm{K}\left(\mathrm{K}_{2} \mathrm{O}\right) \mathrm{ha}^{-1}$, after taking into account a planting density of 62,500 plants $\mathrm{ha}^{-1}$ ] aimed to strongly increase leaf nutrient concentrations allowing the establishment of higher limits of sufficiency ranges. The preference for conventional fertilizers was due to their higher solubility and availability to plants. The fertilization plan was split into four applications during the growing season. The pots were filled with $15 \mathrm{~kg}$ of dry and sieved ( $2 \mathrm{~mm}$ mesh) soil mixed with $15 \mathrm{~g}$ perlite $\mathrm{kg}^{-1}$ dry soil. The pots were also placed in holes in the ground lined with PVC pipe to prevent direct sunlight reaching the walls of the pots.

\section{Sample collection and tissue analyses}

In the region, lemon balm is usually managed on a regime of multiple cuts during the summer growing season. In winter, the plants undergo a resting period due to the winter frost. In the field trial, the plants were harvested three and four times, respectively in 2013 and 2014. The dates of sampling were 15 July, 2 September, and 4 November in 2013 and 7 May, 25 June, 12 August, and 6 October in 2014. In each cut, six plants from the inner rows of the plots were randomly selected. A subsample of young mature leaves was used for elemental analysis to serve as the standard tissue for the establishment of the sufficiency ranges. The remaining sample was separated into leaves and stems and used to estimate dry matter yield and plant nutrient recovery. The plants were cut at $\sim 10 \mathrm{~cm}$ from the ground on early flowering. All tissue materials were oven dried at $65^{\circ} \mathrm{C}$, weighed and ground. Tissue analyses were performed by Kjeldahl $(\mathrm{N})$, colorimetry (P and $\mathrm{B})$, flame emission spectrometry $(\mathrm{K})$, and atomic absorption spectrometry ( $\mathrm{Ca}, \mathrm{Mg}, \mathrm{Cu}, \mathrm{Fe}, \mathrm{Zn}$, and $\mathrm{Mn}$ ) methods.

Plants of the pot experiment of 2013 were harvested four times during the growing season, on 7 May, 11 June, 12 August, and 4 October. The dates of sampling in 2014 were 23 June, 30 July, 10 September, and 23 October. In 2015, the dates of sampling were 22 June, 5 August, and 27 November. The harvesting method, pre-treatment of plant samples, and tissue analysis were the same as reported for the field experiment.

Estimates of greenness or relative chlorophyll content in plant leaves were recorded by using the portable SPAD-502 plus chlorophyll meter (Spectrum Technologies, Inc., Plainfield, IL, USA). The tool estimates the SPAD-readings from the amount of light transmitted by the leaf in two wavelength regions in which the chlorophyll pigments absorb $(650 \mathrm{~nm}$, red light) and do not absorb (940 nm, infrared light) the radiation passing through the leaf. The readings were taken from the blade of fully expanded young leaves. SPAD readings were taken from the field experiments on 2 September 2013 and 7 May, 25 June, 12 August, and 6 October 2014 and from the pot experiments on 22 June, 5 August, and 27 October 2015.

\section{Data analysis}

The effect of the fertilizer treatments on dry matter yield of stems, leaves, and total was subjected to analysis of variance (ANOVA). When significant differences among treatments occurred, the means were separated by the Tukey HSD test $(\alpha=0.05)$. 
Critical nutrient concentration is defined as the point in the curve of the relationship between tissue nutrient concentration and yield below or above which there is, respectively, a high or low probability of obtaining a positive response of the crop if more nutrient is applied (Rodrigues et al. 2005). Based on that relationship, a critical toxic (or excessive) tissue nutrient concentration can also be defined. To establish sufficiency ranges, tissue nutrient concentrations were divided into three classes: deficient; adequate; and excessive. The boundaries of the adequate range are set by the threshold values defined above. In this work, when a positive response to a given nutrient is found, critical nutrient concentrations were determined by the graphical method of Cate-Nelson (Cate and Nelson 1971), modified by declaring the horizontal line at a fixed value (Rodrigues 2004). From the relationship between leaf nutrient concentration and relative yield, a horizontal line was fixed at $90 \%$ of relative yield, and the vertical line was free to keep the greatest amount of points in the positive quadrants. The Cate-Nelson technique is usually used in these kinds of studies since it can overcome the difficulty in obtaining a good relationship between tissue nutrient concentration and yield. Relative yields were estimated as the percentage of the maximum yield obtained in each individual experiment. The procedure allows removing most of the experimental variability and comparing critical values from a wide range of conditions. The sufficiency ranges of nutrients for which a response from the crop was not found, or those not included in the experimental design, were estimated by removing $10 \%$ of extreme high and low points of the scatterplot, since they probably are outliers associated with experimental error.

Crop nutrient removals were estimated from the highly productive plots of each experiment by multiplying dry matter yield and tissue nutrient concentration after plant samples had been split into leaves and stems, weighed and analyzed separately. The results were expressed per ton of dry biomass.

\section{Results}

\section{Crop response to fertilizer application}

Lemon balm dry matter yield significantly increased in response to $\mathrm{N}$ application on almost all the sampling dates of the field trial and pot experiments. Data of the field trial of 2014 are presented in Figure 2. Leaf and total dry matter yields increased respectively from 9.0 to $15.3 \mathrm{~g} \mathrm{plant}^{-1}$ and 35.8 to $55.2 \mathrm{~g} \mathrm{plant}^{-1}$ from the control treatment of the highest $\mathrm{N}$ rate.

In the pot experiments, the response of lemon balm to $\mathrm{N}$ application followed a similar trend as observed in Figure 2. However, in the PotN2015, where a treatment consisting of a very high rate of N was included, a plateau was observed where leaf and total dry matter yields did not increase with increased rates of applied $\mathrm{N}$ (Figure 3).

Lemon balm did not respond to $P$ fertilization. In a total of 14 cuts of biomass, corresponding to the four P fertilization trials, no significant response to $\mathrm{P}$ application was found. The same occurred for $\mathrm{K}$ fertilization. In this study, no significant response by lemon balm to applied $\mathrm{K}$ was found, either in the field trial or in the pot experiments.
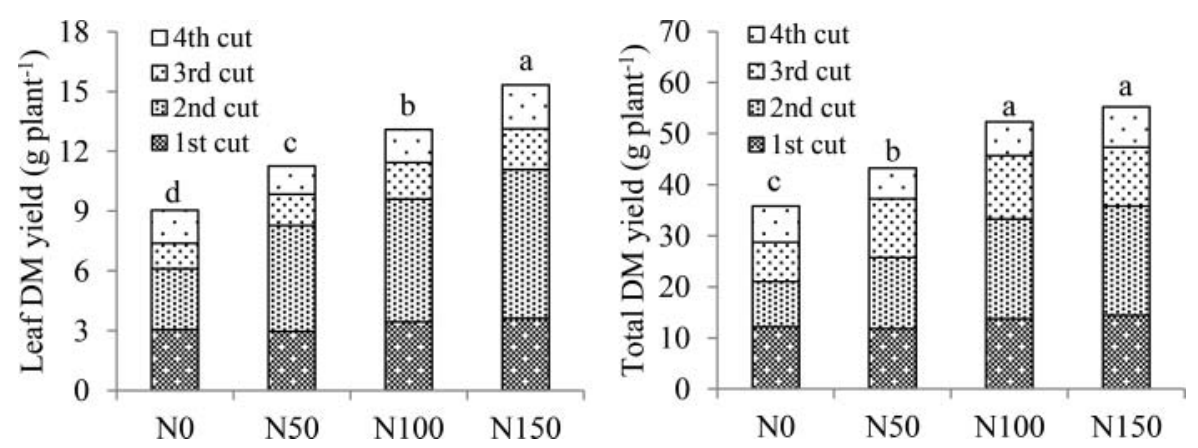

Figure 2. Leaf (left) and total (leaves + stems) (right) dry matter (DM) yield of lemon balm grown in the field trial of 2014 as a function of four $\mathrm{N}$ rates $\left[0\right.$ (N0), 50 (N50), 100 (N100), 150 (N150) kg ha ${ }^{-1}$ ]. Letters above the columns is the result of the Tukey HSD test $(\alpha=0.05)$ for the sum of DM yields of the four cuts of vegetation. 

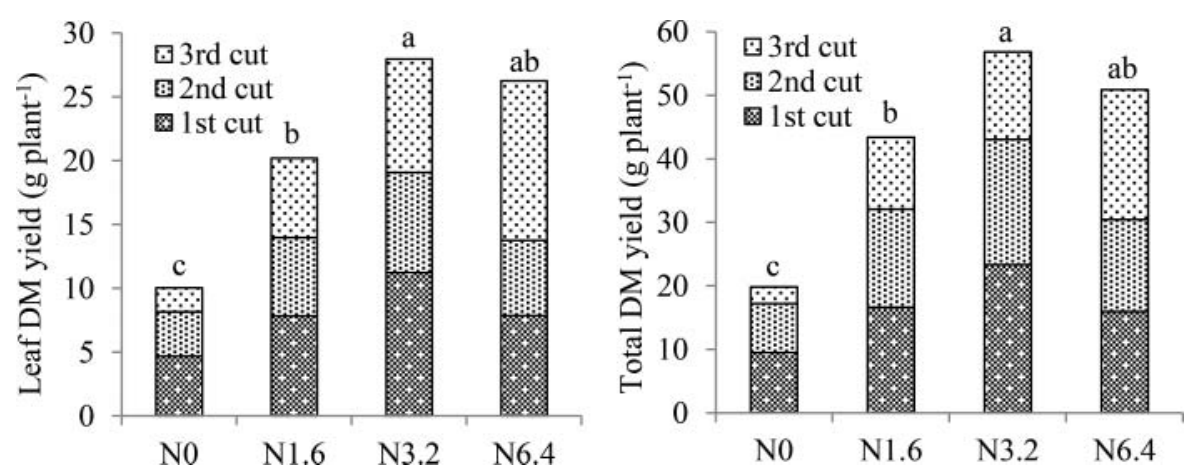

Figure 3. Leaf (left) and total (leaves + stems) (right) dry matter (DM) yield of lemon balm grown in the pot experiment carried out in 2015 as a function of four $\mathrm{N}$ rates [0 (N0), 1.6 (N1.6), 3.2 (N3.2), 6.4 (N6.4) $\mathrm{g} \mathrm{pot}^{-1}$ ]. Letters above the columns is the result of the Tukey HSD test $(\alpha=0.05)$ for the sum of DM yields of the three cuts of vegetation.

Plants did not respond to B fertilization. However, when B was applied at excessively high rates (PotB2015) a significant decrease in dry matter yield was found (Figure 4). In the treatment consisting of $128 \mathrm{mg} \mathrm{B}^{\mathrm{B}}$ pot $^{-1}$ only 3.8 and $5.7 \mathrm{~g} \mathrm{plant}^{-1}$, respectively of leaf and total dry matter were recorded while in the control treatment much higher values were found, respectively 24.2 and $49.5 \mathrm{~g} \mathrm{plant}^{-1}$.

\section{Sufficiency ranges}

Critical leaf $\mathrm{N}$ concentration, which corresponds to the lower limit of the sufficiency range for $\mathrm{N}$, was set as the average of the critical or threshold values of 18 plots obtained from the relationship between leaf $\mathrm{N}$ concentration and relative dry matter yield. The procedure is exemplified in Figure 5a by using data from the harvest of 23 June of the pot experiment of 2014. The values of all the 18 plots varied from 22 to $31 \mathrm{~g} \mathrm{~kg}^{-1}$ averaging $27 \mathrm{~g} \mathrm{~kg}^{-1}$. Critical leaf $\mathrm{N}$ concentrations for the individual plots remained stable, below and above average over time, which gave $27 \mathrm{~g} \mathrm{~kg}^{-1}$ for the lower limit of the sufficiency range for the entire growing season. The critical excessive leaf $\mathrm{N}$ concentration was set as the average of leaf $\mathrm{N}$ concentrations of the plants receiving an excessive rate of $\mathrm{N}$. From the pot experiment of 2015, data of the harvest of 27 October is presented in Figure $5 \mathrm{~b}$ as an example. By using data from all the harvests of this pot experiment, an average value of $40 \mathrm{~g} \mathrm{~kg}^{-1}$ was estimated which became the proposal for the higher limit of the sufficiency range for $\mathrm{N}$.

Lemon balm did not respond to $\mathrm{P}$ application. The sufficiency range for $\mathrm{P}$ was established by removing $\sim 10 \%$ of values away from the center of the scatterplot, which probably are outliers associated with experimental error. From the individual plots it was observed that leaf $\mathrm{P}$ concentrations
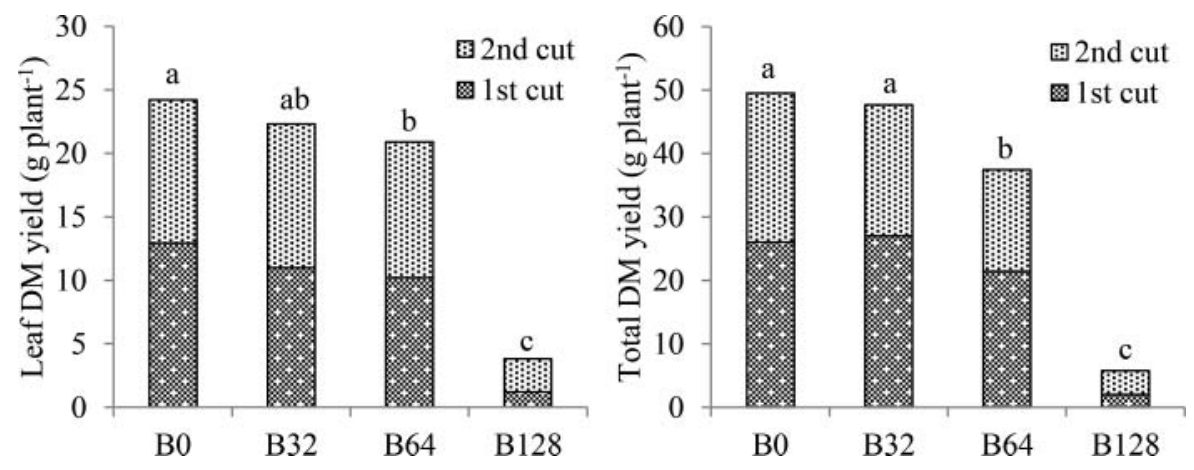

Figure 4. Leaf (left) and total (leaves + stems) (right) dry matter (DM) yield of lemon balm grown in the pot experiment carried out in 2015 as a function of four B rates $\left(0,32,64,128 \mathrm{mg} \mathrm{pot}^{-1}\right)$. The experiment was managed in two cuts (22 June and 5 August) during the growing season. Letters above the columns is the result of the Tukey HSD test $(\alpha=0.05)$ for the sum of DM yields of the two cuts of vegetation. 

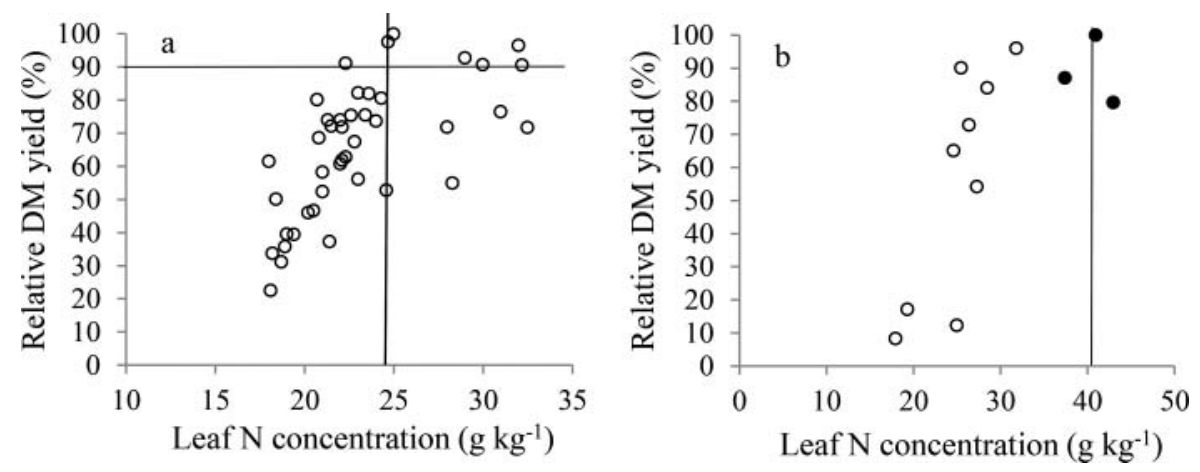

Figure 5. Critical leaf $\mathrm{N}$ concentration (a) estimated from the relationship between leaf $\mathrm{N}$ concentration and relative dry matter (DM) yield by using the Cate-Nelson technique (data from the harvest of 23 June of the pot experiment of 2014), and critical excessive leaf $\mathrm{N}$ concentration (b) established from the average of the leaf $\mathrm{N}$ concentrations of the plants excessively fertilized with $\mathrm{N}$ (full symbols) (data of the harvest of 27 October of the pot experiment of 2015).

consistently increased from the first to the last harvests over the growing season. Thus, the harvest dates were separated into two groups, from May to August and September to November. The two scatterplots used to set the sufficiency ranges for $\mathrm{P}$ are presented in Figure 6.

As observed for $\mathrm{P}$, no significant response by lemon balm was found to $\mathrm{K}$ application. Leaf $\mathrm{K}$ concentrations also tended to increase throughout the growing season. Thus, the sufficiency ranges for $\mathrm{K}$ were estimated as reported for P (Figure 7).

In this study, considering all the experiments and dates of cut, no positive response to B application was found. However, when excessive B rates were used, aimed at establishing the higher limit of the sufficiency range, a significant decrease in dry matter yield was found (Figure 4). In this particular situation, critical leaf B concentration was set as the average of the lower values of all the B0 (B zero) treatments. The value found was $\sim 18 \mathrm{mg} \mathrm{B} \mathrm{kg}^{-1}$, this being the value proposed for the lower limit of the sufficiency range. From the pots excessively fertilized with $B$, a decrease in dry biomass yield was found when the leaves contained between 75 and $150 \mathrm{mg} \mathrm{B} \mathrm{kg}^{-1}$. The harvest of 5 August of the PotB2015 (Figure 8) shows one of those situations. The average of all the dates of cut gave $125 \mathrm{mg} \mathrm{B} \mathrm{kg}^{-1}$, a leaf $\mathrm{B}$ concentration which will become the proposal for the higher limit of the sufficiency range.

The methodology for establishing sufficiency ranges for the nutrients analyzed from plant tissues, but not included in the experimental design $(\mathrm{Ca}, \mathrm{Mg}, \mathrm{Cu}, \mathrm{Fe}, \mathrm{Zn}$, and $\mathrm{Mn}$ ), was the same as reported for the nutrients for which a response by dry matter yield to nutrient application was not found. Approximately $10 \%$ of the values positioned away from the center of the scatterplot were removed. This was to avoid incorporate outliers associated with experimental error, maintaining only those in
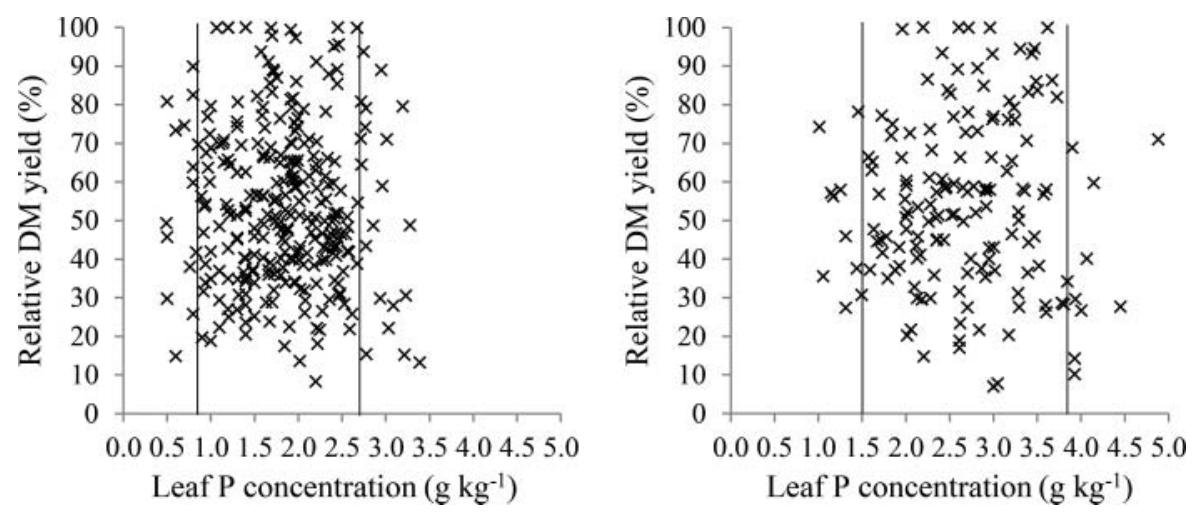

Figure 6. Sufficiency ranges for leaf $P$ based on removing $\sim 10 \%$ of values away from the center of the scatterplot. Two set of data were established taking into account the variation in leaf $\mathrm{P}$ concentration observed during the growing season. Data were grouped into May, June, July, and August (left) and September, October, and November (right). 

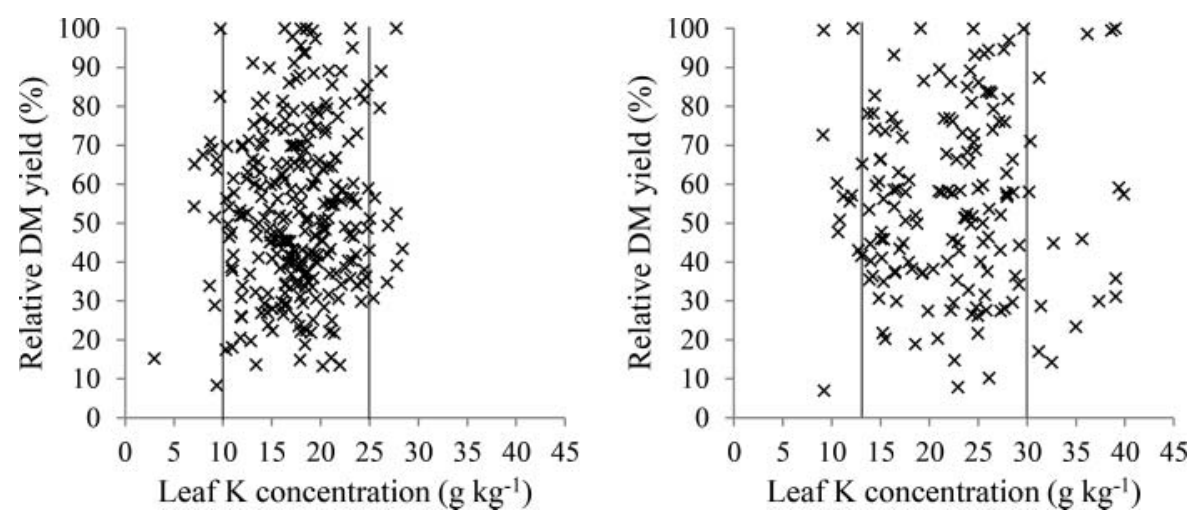

Figure 7. Sufficiency ranges for leaf $\mathrm{K}$ based on removing $\sim 10 \%$ of values away from the center of the scatterplot. Two set of data were established taking into account the variation observed in leaf $\mathrm{K}$ concentration during the growing season. Data were grouped into May, June, July, and August (left) and September, October, and November (right).

the range where the probability of occurrence is much higher. The scatterplots establishing the sufficiency ranges for $\mathrm{Ca}, \mathrm{Mg}, \mathrm{Cu}, \mathrm{Fe}, \mathrm{Zn}$, and $\mathrm{Mn}$ are presented in Figure 9.

To set critical SPAD-readings the Cate-Nelson technique was applied to a total of eight plots. That corresponding to the harvest of 6 October of the field trial of 2014 is shown in Figure 10a. A value of 30 was found as the average of the eight plots, being the proposal for the lower limit of the sufficiency range. The higher limit of the sufficiency range was estimated as the average of SPAD-readings of the plots excessively fertilized with N. The procedure is presented in Figure 10b. The estimated value was 45 which is proposed as the higher limit of the sufficiency range.

Table 2 summarizes the sufficiency ranges established for macro and micronutrients and SPAD readings. In the case of $\mathrm{P}$ and $\mathrm{K}$, different sufficiency ranges were proposed for the first and second halves of the growing season since leaf concentrations of both the nutrients increased as the growing season progressed.

\section{Crop nutrient removal}

Crop nutrient removals were estimated from the plants grown in the most productive plots, multiplying leaf and stem dry matter yields by the nutrient concentrations in the respective plant part. The results were expressed as $\mathrm{kg}$ (macronutrients) or $\mathrm{g}$ (micronutrients) per ton of dry biomass (Table 3). The total removals of macronutrients per ton of dry biomass in a cultivated field of lemon balm were estimated in 27.7, 2.2, 16.9, 9.2, and $4.7 \mathrm{~kg}$, respectively, for $\mathrm{N}, \mathrm{P}, \mathrm{K}, \mathrm{Ca}$, and $\mathrm{Mg}$.

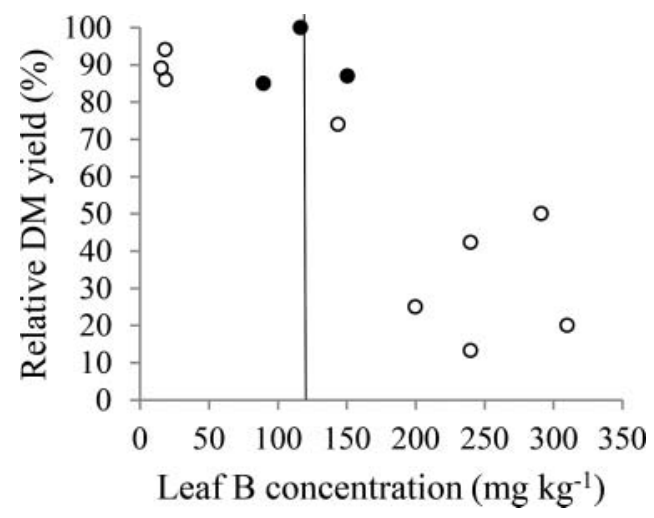

Figure 8. Higher limit of the sufficiency range established from the average of leaf B concentrations of the plants of the plot fertilized with the higher B rate from which a decrease in dry matter (DM) yield was not found (full symbols). Data from the harvest of 5 August of the pot experiment of 2015. 

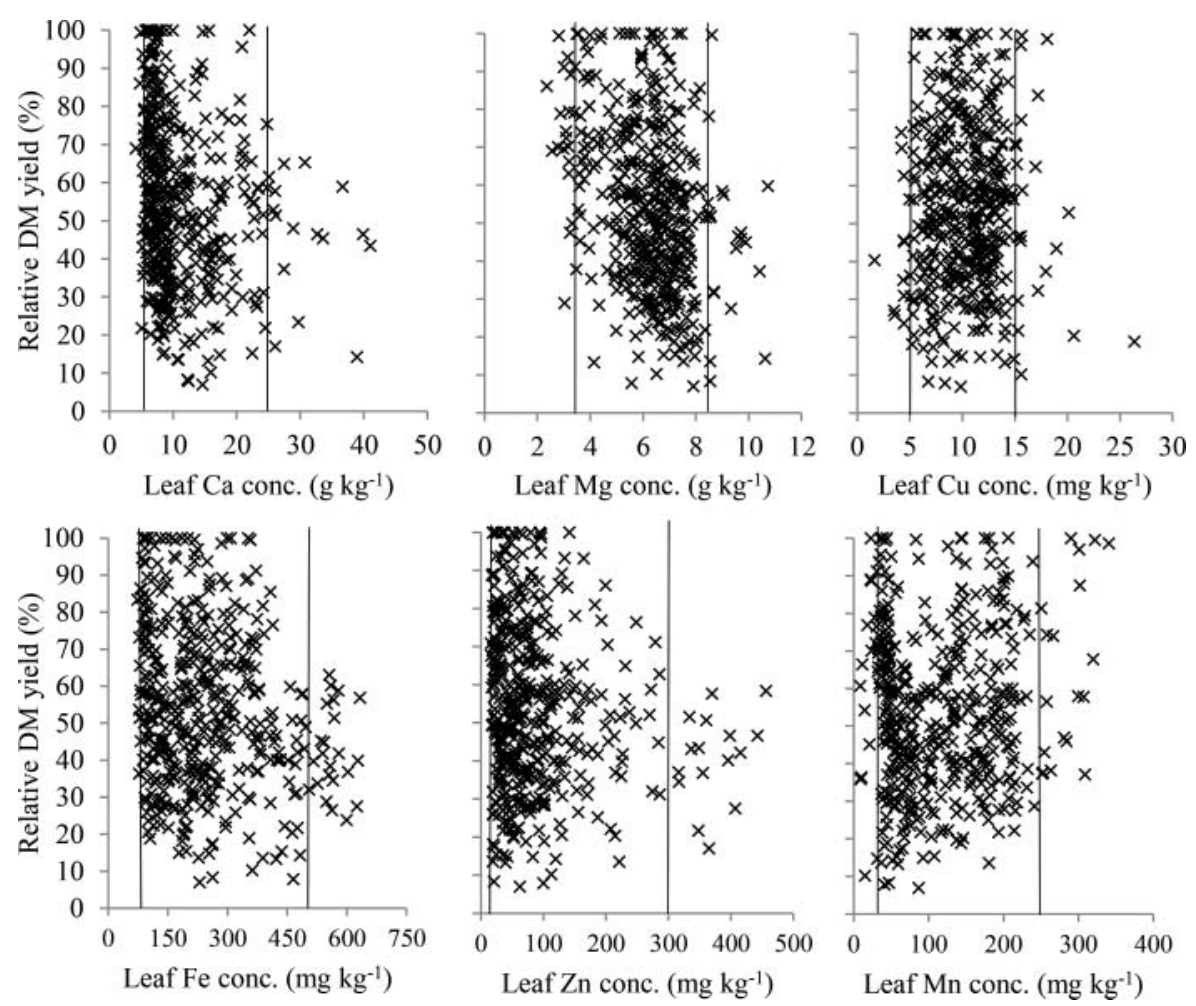

Figure 9. Sufficiency ranges for leaf $\mathrm{Ca}, \mathrm{Mg}, \mathrm{Fe}, \mathrm{Zn}, \mathrm{Cu}$, and $\mathrm{Mn}$ after removing $\sim 10 \%$ of the extreme higher and lower values of each plot.

\section{Discussion}

Dry matter yield of lemon balm significantly increased with $\mathrm{N}$ applied as a fertilizer on almost all the harvest dates of the field and pot experiments. A previous study in Brazil had also shown that lemon balm responded almost linearly to relatively high $\mathrm{N}$ rates $\left(180 \mathrm{~kg} \mathrm{ha}^{-1}\right)$ (May et al. 2008). From an experiment carried out in Iran, Németh-Zámboriné et al. (2015) reported that a moderate $\mathrm{N}$ rate (90 $\mathrm{kg} \mathrm{ha}^{-1}$ ) was enough to maximize dry matter yield and essential oil content in the biomass. The response to applied $\mathrm{N}$ is the most common result from agricultural crops. Studies from the region of Bragança have shown positive responses to applied $\mathrm{N}$ in several herbaceous and perennial tree crops, such as potato (Solanum tuberosum L.) (Rodrigues et al. 2005), maize (Zea mays L.) (Rodrigues et al.
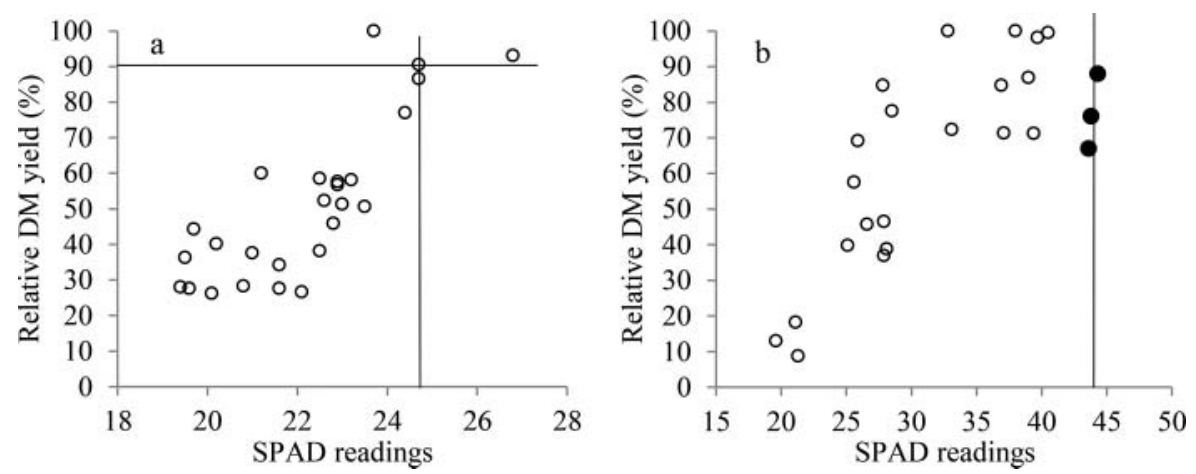

Figure 10. Critical SPAD reading (a) for lemon balm estimated by the Cate-Nelson technique (data from the harvest of 6 October 2014 of the field trial), and higher limit of the sufficiency range (b) established from the average of the SPAD readings recorded in plants excessively fertilized with $\mathrm{N}$ (full symbols). 
Table 2. Sufficiency ranges for macro and micronutrients and SPAD-readings.

\begin{tabular}{|c|c|c|c|c|}
\hline \multicolumn{3}{|c|}{ Macronutrients $\left(\mathrm{g} \mathrm{kg}^{-1}\right)$} & \multicolumn{2}{|c|}{ Micronutrients $\left(\mathrm{mg} \mathrm{kg}^{-1}\right)$} \\
\hline Nitrogen & \multicolumn{2}{|c|}{$27.0-40.0$} & Boron & $18-125$ \\
\hline Phosphorus & $0.8-2.7^{\dagger}$ & $1.5-3.8^{\ddagger}$ & Copper & $5-25$ \\
\hline Potassium & $10.0-25.0^{\dagger}$ & $18.0-30.0^{\ddagger}$ & Iron & $75-500$ \\
\hline Calcium & \multirow{3}{*}{\multicolumn{2}{|c|}{$\begin{array}{l}\text { 5.0- } 25.0 \\
3.5-8.5 \\
\text { SPAD-readings }\end{array}$}} & Zinc & $20-300$ \\
\hline Magnesium & & & Manganese & $30-250$ \\
\hline & & & $30-45$ & \\
\hline
\end{tabular}

${ }^{\dagger}$ May to August; ${ }^{\ddagger}$ September to November.

2006), Jerusalem artichoke (Helianthus tuberosus L.) (Rodrigues et al. 2007), stevia [Stevia rebaudiana (Bertoni)] (Rodrigues et al. 2016), and olive (Olea europaea L.) (Rodrigues et al. 2011). This is likely due to the fact that $\mathrm{N}$ does not accumulate in soils in readily available forms to plants. $\mathrm{N}$ should be applied annually as fertilizers or manures to agricultural soils or be allowed to enter the soil through a natural process, such as biological dinitrogen fixation (Rodrigues et al. 2013, 2015).

Lemon balm did not respond to applied P and K. Sharafzadeh, Khosh-Khui, and Javidnia (2011) also did not find an increase in dry matter yield of lemon balm in response to $\mathrm{P}$ application. However, the authors reported a positive effect on lemon balm dry matter yield from a NP treatment. NémethZámboriné et al. (2015) also reported positive effects on dry matter yield of lemon balm from applied $\mathrm{P}$ and $\mathrm{K}$, but in combination with other nutrients, respectively in NPMg and NPKMg treatments. There are no studies reporting the effect of the application of B on lemon balm. In the present study, a positive response to the applied B was not found. However, B is a frequent nutritional disorder in the region, mainly in dicots when rainfed-managed (Arrobas et al. 2010; Portela and Louzada 2012). Since lemon balm was watered during the summer growing season, probably the irrigation water had supplied enough B to reduce the response to B applied as a fertilizer. Excessive B rates severely damaged the crop and reduced dry matter yield. It is well-known that the sufficiency ranges for B are usually narrower than those of other nutrients which increase the risk of B toxicity (Gupta 1993; Nable, Bañuelos, and Paull, 1997) and may explain the result that was obtained. Studies using manures have reported an increase in lemon balm performance and in essential oil concentration in plant tissues (Santos et al. 2009; Sodré et al. 2013), probably as a result of nutrient release, particularly N, and an improvement in general soil fertility.

Threshold values or sufficiency ranges for lemon balm are not yet available in the literature. Even elemental analysis of plant tissue can hardly be found from previous work. Blank et al. (2006), from a pot experiment carried out in a greenhouse, reported leaf nutrient concentrations in plants subjected to a complete fertilization plan $(\mathrm{N}+\mathrm{P}+\mathrm{K}+\mathrm{S}+\mathrm{B}+\mathrm{Cu}+\mathrm{Fe}+\mathrm{Zn}+$ liming $)$ and to other fertilization treatments where each one of the nutrients were individually removed. In general, all the nutrients analyzed fell within the sufficiency ranges that are reported in the present work. From a brief comparison of the

Table 3. Nutrient removal (average \pm standard error) in the aerial biomass of lemon balm estimated from the most productive fertilizer treatments.

\begin{tabular}{lcrr}
\hline & \multicolumn{3}{c}{ Nutrient removal } \\
\cline { 2 - 4 } & \multicolumn{1}{c}{ Leaves } & Stems & Total (leaves + stems) \\
\hline Nitrogen $\left(\mathrm{kg} \mathrm{t}^{-1} \mathrm{DM}\right)$ & $10.0 \pm 1.37$ & $1.77 \pm 5.30$ & $27.7 \pm 5.54$ \\
Phosphorus $\left(\mathrm{kg} \mathrm{t}^{-1} \mathrm{DM}\right)$ & $0.7 \pm 0.17$ & $1.5 \pm 0.21$ & $2.2 \pm 0.35$ \\
Potassium $\left(\mathrm{kg} \mathrm{t}^{-1} \mathrm{DM}\right)$ & $4.9 \pm 1.10$ & $12.0 \pm 1.68$ & $16.9 \pm 2.32$ \\
Calcium $\left(\mathrm{kg} \mathrm{t}^{-1} \mathrm{DM}\right)$ & $3.4 \pm 1.11$ & $5.8 \pm 1.06$ & $9.2 \pm 1.94$ \\
Magnesium kg t & $1.9 \pm 0.68$ & $2.8 \pm 0.59$ & $4.7 \pm 1.19$ \\
Boron $\left(\mathrm{g} \mathrm{t}^{-1} \mathrm{DM}\right)$ & $36.8 \pm 3.78$ & $23.8 \pm 1.40$ & $60.6 \pm 5.05$ \\
Iron $\left(\mathrm{g} \mathrm{t}^{-1} \mathrm{DM}\right)$ & $106.8 \pm 33.94$ & $123.9 \pm 50.78$ & $230.7 \pm 63.33$ \\
Copper (g t & & $6.7 \pm 1.64$ & $10.1 \pm 2.09$ \\
Zinc $\left(\mathrm{g} \mathrm{t}^{-1} \mathrm{DM}\right)$ & $3.5 \pm 1.24$ & $22.8 \pm 6.16$ & $39.8 \pm 23.80$ \\
Manganese $(\mathrm{g} \mathrm{t}$ & $17.0 \pm 19.28$ & $33.4 \pm 9.48$ & $52.0 \pm 14.34$ \\
\hline
\end{tabular}


sufficiency ranges proposed here for lemon balm with those reported by Bryson et al. (2014) for some major herbaceous (winter wheat, potatoes, ...) or perennial (vine, olive, ...) crops widely grown in the region, it is possible to note that the order of magnitude is similar but with specific differences for individual nutrients or species.

Crop nutrient removal is a function of aboveground dry matter yield and tissue nutrient concentration, data for which does not seem to be available in the literature for lemon balm. There are studies, although few, reporting dry matter yield of lemon balm in different growing conditions, such as field, greenhouses, and pots (May et al. 2008; Luz et al. 2014). Comparing the results of those authors to these here reported and expressed on an area basis, they are not very dissimilar. It is expected that dry matter yield can greatly vary across the world, depending on the general growing conditions. To overcome the situation and increase the worldwide potential use of the present data, crop nutrient removals are here expressed per ton of dry biomass.

\section{Conclusions}

Lemon balm showed a strong response to $\mathrm{N}$ applied as a fertilizer in the conditions of these experiments, which means that the crop should be properly fertilized to achieve high yields. In contrast, there was no significant response to applied P, K, or B. Sufficiency ranges for ten essential nutrients were made available, which will allow the diagnosis of the nutritional status of lemon balm by means of plant analysis by comparing actual leaf nutrient concentrations with the sufficiency ranges here reported. These values are valid for phenological stages close to the time of commercial harvest. Data of crop removal for ten important macro and micronutrients were also provided, which can help in establishing fertilizer recommendations for this crop, since crop nutrient removals provide a direct measure of crop needs.

\section{Acknowledgment}

The authors wish to thank José Montanha for meteorological data.

\section{Funding}

The project "Sustainable management of medicinal and aromatic plants" (PRODER 46025) provided financial support.

\section{References}

Arrobas, M., J. I. Lopes, F. Pavão, J. E. Cabanas, and M. A. Rodrigues. 2010. Comparative boron nutritional diagnosis for olive based on July and January leaf samplings. Communications in Soil Science and Plant Analysis 41:709-20. doi:10.1080/00103620903563949.

Ashori, A., Y. Hamzeh, and F. Amani. 2011. Lemon balm (Melissa officinalis) stalk: chemical composition and fiber morphology. Journal of Polymers and the Environment 19:297-300. doi:10.1007/s10924-010-0279-8.

Babulka, P. 2005. La mélisse (Melissa officinalis L). Phytothérapie 3:114-17. doi:10.1007/s10298-005-0084-Z.

Biasi, L. A., A. P. J. Kowalski, D. Signor, M. A. Alves, F. I. Lima, and C. Deschamps. 2009. Tipos de cobertura do solo e épocas de colheita na produção de melissa. Horticultura Brasileira 27:314-18. doi:10.1590/S010205362009000300009 .

Blank, A. F., A. S. Oliveira, M. F. Arrigoni-Blank, and V. Faquin. 2006. Efeitos da adubação química e da calagem na nutrição de melissa e hortelã-pimenta. Horticultura Brasileira 24:195-98. doi:10.1590/S0102-05362006000200014.

Blank, A. F., S. M. Fontes, A. S. Oliveira, M. C. Mendonça, R. Silva-Mann, and M. F. Arrigoni-Blank. 2005. Produção de mudas, altura e intervalo de corte em melissa. Horticultura Brasileira 23:780-84. doi:10.1590/S010205362005000300018 .

Bryson, G., H. A. Mills, D. N. Sasseville, J. B. Jones Jr., and A. V. Barker. 2014. Plant Analysis Handbook III. A guide to sampling, preparation, analysis and interpretation for agronomic and horticultural crops. Athens, GA: Micro-Macro Publishing, Inc.

Cate Jr, R. B., and L. A. Nelson. 1971. A simple statistical procedure for portioning soil test correlation data into two classes. Soil Science Society of America Proceedings 35:658-60. doi:10.2136/sssaj1971.03615995003500040048x. 
Cunha, A. P., M. T. Nogueira, and O. R. Roque. 2012. Plantas aromáticas e óleos essenciais: composição e aplicações. Lisboa: Fundação Calouste Gulbenkian.

Dias, M. I., L. Barros, M. J. Sousa, and I. C. F. R. Ferreira. 2012. Systematic comparison of nutraceuticals and antioxidant potential of cultivated, in vitro cultured and commercial Melissa officinalis samples. Food and Chemical Toxicology 50:1866-73. doi:10.1016/j.fct.2012.03.057.

Egnér, H., R. Riehm, and W. R. Domingo. 1960. Untersuchungen iber die chemische Bodenanalyse als Grundlag fur die Beurteilunger des Nahrstoffzustandes der Boden, II: Chemische Extractionsmethoden zur Phosphor, und Kalium-bestimmung. Kunglia Lantbrukshogskolans Annaler 26:199-215.

Ghamarnia, H., F. Mousabeygi, and I. Arji. 2015. Lemon balm (Melissa officinalis L) water requirement, crop coefficients determination and SIMDualKc model implementing. European Journal of Medicinal Plants 5:281-96. doi:10.9734/ EJMP/2015/14138.

Grünwald, J., and C. Jänicke. 2009. Grüne apotheke (Green pharmacy) Grafe and Unzer Verlag. München: GmbH.

Gupta, U. C. 1993. Deficiency, sufficiency, and toxicity levels of boron in crops. In Boron and its role in crop production, ed. U. C. Gupta, 137-45. Boca Raton: CRC Press (FL).

Kamdem, J. P., A. Adeniran, A. A. Boligon, C. V. Klimaczewski, O. O. Elekofehinti, W. Hassan, M. Ibrahim, E. P. Waczuk, D. F. Meinerz, and M. L. Athayde. 2013. Antioxidant activity, genotoxicity and cytotoxicity evaluation of lemon balm (Melissa officinalis L) ethanolic extract: its potential role in neuroprotection. Industrial Crops and Products 51:26-34. doi:10.1016/j.indcrop.2013.08.056.

León-Fernández, M., E. Sánchez-Govín, C. E. Quijano-Celis, and J. A. Pino. 2008. Effect of planting practice and harvest time in oil content and its composition in Melissa officinalis L cultivated in Cuba. Journal of Essential Oil Bearing Plants 11:62-68. doi:10.1080/0972060X.2008.10643599.

López, V., S. Martín, M. Gómez-Serranillos, M. Carretero, A. Jäger, and M. Calvo. 2009. Neuroprotective and neurological properties of Melissa officinalis. Neurochemical Research 34:1955-61. doi:10.1007/s11064-009-9981-0.

Luño, V., L. Gil, M. Olaciregui, R. A. Jerez, I. Blas, and F. Hozbor. 2015. Antioxidant effect of lemon balm (Melissa officinalis) and mate tea (Ilex paraguensys) on quality, lipid peroxidation and DNA oxidation of cryopreserved boar epididymal spermatozoa. Andrologia 47:1004-11. doi:10.1111/and.12370.

Luz, J. M. Q., S. M. Silva, L. L. Habber, and M. O. M. Marquez. 2014. Essential oil of Melissa officinalis L at different seasons, systems of planting and fertilizations. Revista Brasileira de Plantas Medicinais 16:552-60. doi:10.1590/1983-084X/11_130.

May, A., A. O. Bovi, L. V. Sacconi, A. G. Samra, and M. Q. Pinheiro. 2008. Produtividade da biomassa de melissa em função de intervalo de cortes e doses de nitrogénio. Horticultura Brasileira 26:312-15. doi:10.1590/S010205362008000300004 .

Motsara, M. R., and R. N. Roy. 2008. Guide to laboratory establishment for plant nutrient analysis. FAO Fertilizer and Plant Nutrition Bulletin 19, Food and Agriculture Organization of the United Nations, Rome.

Nable, R. O., G. S. Bañuelos, and J. G. Paull. 1997. Boron toxicity. Plant and Soil 198:181-98. doi:10.1023/ A:1004272227886.

Németh-Zámboriné, E., K. Szabó, P. Rajhárt, L. Lelik, J. Bernáth, and T. Popp. 2015. Effect of nutrients on drug production and essential oil content of lemon balm (Melissa officinalis L). Journal of .Essential Oil Bearing Plants 18:150815. doi:10.1080/0972060X.2014.935040.

Pereira, R. P., A. A. Boligon, A. S. Appel, R. Fachinetto, C. S. Ceron, J. E. Tanus-Santos, M. L. Athayde, and J. B. T. Rocha. 2014. Chemical composition, antioxidant and anticholinesterase activity of Melissa officinalis. Industrial Crops and Products 53:34-45. doi:10.1016/j.indcrop.2013.12.007.

Portela, E. M., and J. L. Louzada. 2012. Early diagnosis of boron deficiency in chestnut. Journal of Plant Nutrition 35:30410. doi:10.1080/01904167.2012.636132.

Rabbani, M., Z. Etemadifar, F. Karamifard, and M. Borhani. 2016. Assessment of the antimicrobial activity of Melissa officinalis and Lawsonia inermis extracts against some bacterial pathogens. Comparative Clinical Pathology 25:59-65. doi:10.1007/s00580-015-2140-x.

Rodrigues, M. A. 2004. Establishment of continuous critical levels for indices of plant and pre-sidedress soil N status in the potato crop. Communications in Soil Science and Plant Analysis 35:2067-85. doi:10.1081/LCSS-200026837.

Rodrigues, M. A., A. Pereira, J. E. Cabanas, L. Dias, J. Pires, and M. Arrobas. 2006. Crops use-efficiency of nitrogen from manures permitted in organic farming. European Journal of Agronomy 25:328-35. doi:10.1016/j.eja.2006.07.002.

Rodrigues, M. A., C. M. Correia, A. M. Claro, I. Q. Ferreira, J. C. Barbosa, J. M. Moutinho-Pereira, E. A. Bacelar, A. A. Fernandes-Silva, and M. Arrobas. 2013. Soil nitrogen availability in olive orchards after mulching legume cover crop residues. Scientia Horticulturae 156:45-51. doi:information: 101016/jscienta201304035. doi:10.1016/j. scienta.2013.04.035.

Rodrigues, M. A., F. Pavão, J. I. Lopes, V. Gomes, M. Arrobas, J. Moutinho-Pereira, S. Ruivo, J. E. Cabanas, and C. M. Correia. 2011. Olive yields and tree nutritional status during a four year period without nitrogen and boron fertilization. Communications in Soil Science and Plant Analysis 42:803-14. doi:10.1080/00103624.2011.552656.

Rodrigues, M. A., J. Coutinho, J. Martins, and M. Arrobas. 2005. Quantitative sidedress nitrogen recommendations for potatoes based upon crop nutritional indices. European Journal of Agronomy 23:79-88. doi:10.1016/j.eja.2004.10.001.

Rodrigues, M. A., L. Sousa, J. E. Cabanas, and M. Arrobas. 2007. Tuber yield and leaf mineral composition of Jerusalem artichoke (Helianthus tuberosus L) grown under different cropping practices. Spanish Journal of Agricultural Research 5:545-53. doi:10.5424/sjar/2007054-275. 
Rodrigues, M. A., P. Dimande, E. Pereira, I. Q. Ferreira, S. Freitas, C. M. Correia, J. Moutinho-Pereira, and M. Arrobas. 2015. Early-maturing annual legumes: an option for cover cropping in rainfed olive orchards. Nutrient Cycling in Agroecosystems 103:153-66. doi:10.1007/s10705-015-9730-5.

Rodrigues, M. A., S. Afonso, I. Q. Ferreira, and M. Arrobas. 2016. Response of stevia to nitrogen fertilization and harvesting regime in Northeastern Portugal. Archives of Agronomy and Soil Science 63 (5):626-637. doi:101080/ 0365034020161230272.

Santos, M. F., M. C. Mendonça, J. L. S. Carvalho Filho, I. B. Dantas, R. Silva-Mann, and A. F. Blank. 2009. Esterco bovino e biofertilizante no cultivo de erva-cidreira-verdadeira (Melissa officinalis L). Revista Brasileira de Plantas Medicinais 11:355-59. doi:10.1590/S1516-05722009000400001.

Sharafzadeh, S., M. Khosh-Khui, and K. Javidnia. 2011. Effects of nutrients on growth and active substances of lemon balm (Melissa officinalis). Acta Horticulturae 925:229-32. doi:10.17660/ActaHortic.2011.925.33.

Sodré, A C. B., L. L. Haber, J. M. Q. Luz, M. O. M. Marques, and C. R. Rodrigues. 2013. Adubação orgânica e mineral em melissa. Horticultura Brasileira 31:147-52. doi:10.1590/S0102-05362013000100023.

Sodré, A. C. B., J. M. Q. Luz, L. L. Haber, M. O. M. Marques, C. R. Rodrigues, and A. F. Blank. 2012. Organic and mineral fertilization and chemical composition of lemon balm (Melissa officinalis) essential oil. Revista Brasileira de Farmacognosia 22:40-44. doi:10.1590/S0102-695X2011005000186.

Sousa, A. C., C. R. Gattass, D. S. Alviano, C. S. Alviano, A. F. Blank, and P. B. Alves. 2004. Melissa officinalis L essential oil: antitumoral and antioxidant activities. Journal of Pharmacy and Pharmacology 56:677-81. doi:10.1211/ 0022357023321

Stanojevic, D., L. Comic, O. Stefanovic, and S. S. Sukdolak. 2010. In vitro synergistic antibacterial activity of Melissa officinalis L and some preservatives. Spanish Journal of Agricultural Research 8:109-15. doi:10.5424/sjar/2010081-1149.

Taiwo, A. E., F. B. Leite, G. M. Lucena, M. Barros, D. Silveira, M. V. Silva, and V. M. Ferreira. 2012. Anxiolytic and antidepressant-like effects of Melissa officinalis (lemon balm) extract in rats: influence of administration and gender. Indian Journal of Pharmacology 44:189-92. doi:10.4103/0253-7613.93846.

Vafaei, A. A., H. Miladi-Gorgi, A. Rashidy-Pour, A. A. Taherian, M. Jarrahi, and M. Emami-Abargoei. 2005. Anxiolytic effects of the aqueous extracts of Melissa officinalis and the role of opioid receptors in mice. Journal of the Neurological Sciences. doi:10.1016/S0022-510X(05)81319-X.

Weidner, C., M. Rousseau, A. Plauth, S. J. Wowro, C. Fischer, H. Abdel-Aziz, and S. Sauer. 2015. Melissa officinalis extract induces apoptosis and inhibits proliferation in colon cancer cells through formation of reactive oxygen species. Phytomedicine 22:262-70. doi:10.1016/j.phymed.2014.12.008.

WRBSR. 2014. World reference base for soil resources 2014. International soil classification system for naming soils and creating legends for soil maps. World soil resources reports - 106, Food and Agriculture Organization of the United Nations, Rome, Italy. 